C O N T R I B U I Ç Ã O E S P E C I A L

\title{
THE NORTHEAST PLAYS FOOTBALL, TOO: WORLD CUP SOCCER AND REGIONAL IDENTITY IN THE BRAZILIAN NORTHEAST ${ }^{\mathrm{i}}$
}

\author{
O Nordeste também joga futebol: a Copa do Mundo e a \\ identidade regional no Nordeste brasileiro \\ El Nordeste también juega fútbol: el Mundial y la identidad \\ regional en el Nordeste brasileño
}

\section{COURTNEY CAMPBELL L ${ }^{*}$}

DOI: http://dx.doi.org/10.1590/S2178-149420190003000009

\footnotetext{
'The research for this article was funded by a Summer Research Award from the College of Arts and Sciences at Vanderbilt University and an Institute of International Education Graduate Fellowship for International Study administered by Fulbright Brazil. The final product was greatly influenced by feedback given generously at the Grupo de Trabalho 09 "Esporte e Sociedade" of the $36^{\circ}$ Encontro Anual da Associação Nacional de Pós-Graduação e Pesquisa em Ciências Sociais in Águas de Lindóia, São Paulo, in 2012; at the Rethinking Sport in the Americas Workshop at Emory University in 2013; and, at the Society for Latin American Studies event in Southampton in 2018. I thank the donors and institutions mentioned above for the generous funding and the organizers and participants at these events. In addition, I express thanks to Marshall C. Eakin, Ty West, Celso Castilho, Eddie Wright-Rios, Lesley Gill, Paula Covington, Joshua Nadel, Túlio Velho Barreto, Santiago Quintero, Bernardo Buarque de Hollanda, and Maria Carolina Morais for feedback on previous versions.

' University of Birmingham, Birmingham, Reino Unido.

* Lecturer in Latin American History, Department of History, University of Birmingham. (c.j.campbell@bham.ac.uk) ORCID iD: https://orcid.org/0000-0001-6918-6382
}

Artigo recebido em 01 de Julho de 2019 e aprovado para publicação em 23 de Setembro de 2019. 
THE NORTHEAST PLAYS FOOTBALL, TOO: WORLD CUP SOCCER AND REGIONAL IDENTITY IN THE BRAZILIAN NORTHEAST

\begin{abstract}
This article examines how ideas about northeastern regional identity circulated in discussions of World Cup football. It first presents the preparations of and discussion around the 1950 World Cup match between Chile and the United States in Recife. Then, it analyzes attention given to World Cup football by regionalist intellectuals and artists, including musicians, clay artists, poets, and authors of cordel literature. This analysis shows that World Cup football provided a space within which the terms of regional (and national) identity were contested and debated, emphasizing the multivalence of regional discourse.
\end{abstract}

PALAVRAS-CHAVE: Football; Regional identity; Popular art; World Cup 1950.

\title{
RESUMO
}

Este artigo examina como as ideias relativas à identidade regional circularam em discussões sobre a Copa do Mundo. Primeiro, apresenta preparações e discussões em torno da partida entre Chile e Estados Unidos em Recife, em 1950. Em seguida, analisa a atenção dada ao torneio por intelectuais e artistas regionais, como músicos, ceramistas, poetas e escritores de literatura de cordel. Esta análise mostra que o futebol do Mundial fornece um espaço no qual os termos da identidade regional (e nacional) foram contestados e debatidos, enfatizando a multivalência do discurso regional.

KEYWORDS: Futebol; Identidade regional; Arte popular; Copa do Mundo de 1950.

\section{RESUMEN}

Este artículo analiza como las ideas sobre identidad regional circularon en discusiones sobre el Mundial de fútbol. Primero, presenta preparaciones y discusiones alrededor de la partida entre Chile y Estados Unidos en Recife, en 1950. Después, discute la atención dada al torneo por intelectuales y artistas regionales, incluyendo músicos, ceramistas, poetas y escritores de literatura de cordel. Este análisis muestra que el fútbol del Mundial provee un espacio dentro del cual los términos de la identidad regional (y nacional) fueron contestados y debatidos, enfatizando la multivalencia del discurso regional.

PALABRAS CLAVE: Fútbol; Identidad regional; Arte popular; Mundial de 1950. 
I $t$ is the final, deciding match of the football tournament. Between three and five thousand fans of the home team discuss possible results. The last match was tied 100 to 100 , but the home team has not practiced all week. Fans of the visiting team enjoy free seating and receive cachaça popsicles upon arrival. The referee, named Berimbau, is nude. The visiting team is shirtless and wears leather hats, and the home team is not wearing trousers. Welcome to the deciding match of the best of three between Satan and the infamous northeastern bandit Lampião, narrated in six-line stanzas, with an ABCBDB rhyme scheme (see Figure 1). This pamphlet, $O$ futebol no inferno: a melhor de três, originally written by José Francisco Soares (n.d.), narrates the fictional match, placing an iconic northeastern historical figure at odds with the fallen angel.

There is an assumption in most work on football that the sport is unifying — it brings the nation together as one. It becomes a blanket or flag, cut of one fabric that covers the entire national territory in an expression of nationhood with common symbols, idols, and cultural representations. It reaches out from the Center of the nation into the Periphery, and from the global to the local, pulling territorially, economically, and socially distinct regions into the national fold. Hobsbawm (1990: 143) stressed the ability of international sporting events to integrate nations as imagined communities represented by "a team of eleven real people." Gilberto Freyre (1938) wrote of the connection between Brazilian football and the Brazilian national character. Ronaldo Helal (1998: 88) stressed that football reveals important traits of a culture, as it is rich in images and representations of the collective. And José Carlos Sebe Bom Meihy (1982: 11) stated that "Certainly football is one of the expressions of the 'Brazilian people's spirit'" (See also: Barreto, 2008).

Yet, 0 futebol no inferno suggests that football, as a force of identity, is not uniform or singular. Instead, this poem points to a complex intermingling of regional, national, and international symbols. It suggests that regional heroes can represent the nation in sporting events of greater geographic (or metaphysical) importance and that regional literature can mimic the reporting of regional and national news media. In the words of Arlei Damo (1999: 88)." In such a geographically extensive, socially stratified, and culturally diverse country, football expresses regional diversity, socio-economic hierarchies, and ethnic and racial differences." 


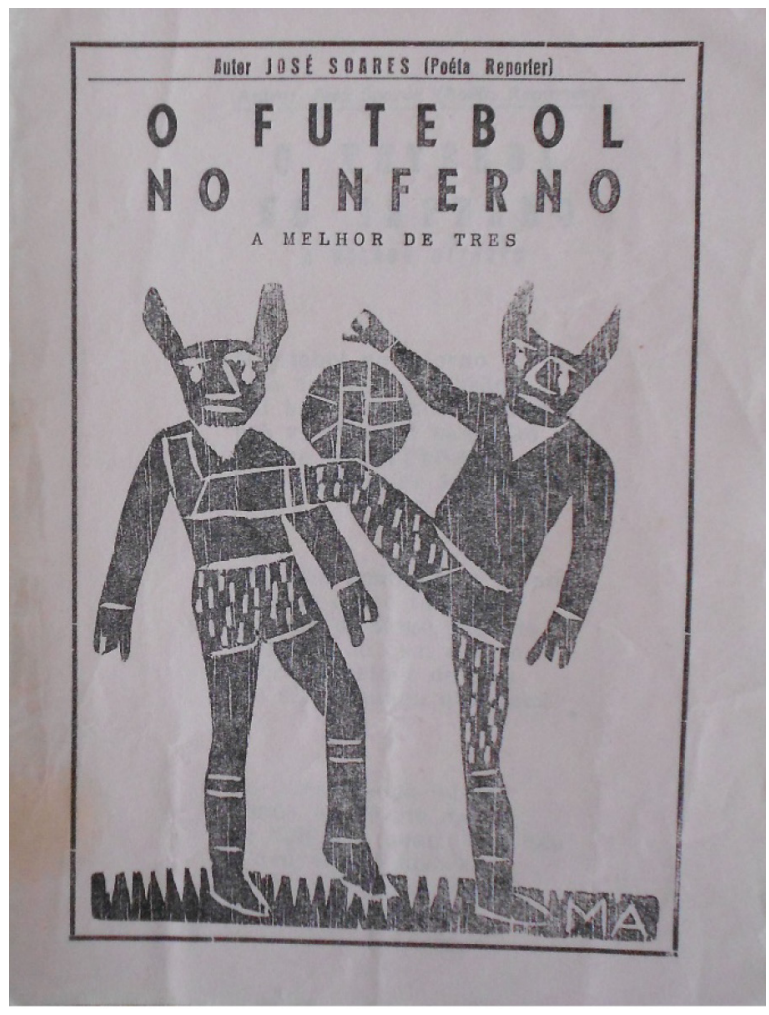

Figure 1: Cover of Futebol no Inferno.

Likewise, in literature on the "invention" of the Northeast, scholars often focus on the consolidation of a regionalizing discourse. These works examine regionalism as an effect of the centralization of the national government or emphasize that the formation of regional identities is an invention of intellectuals, artists, professionals, and bureaucrats (See, for example, Albuquerque Júnior, 2009; 2014; Blake, 2011; Oliven, 1986; 1992; Weinstein, 1982; 2015). This article adds that within regional discourse, there was disagreement, fear, anxiety, criticism, nuance, and general pushback, showing the multivalent character and uneven contour of regional identity. In this way, football is not just a force of identity, but also a space within which debate about regional and national identity takes place. It is in these spaces that identity lives, bends, and kicks instead of being passively stated.

This article examines how ideas about northeastern regional identity circulated in discussions of World Cup football. It first presents newspaper coverage of the 1950 World Cup match between Chile and the United States in the city of Recife. Then, it analyzes World Cup football in regional art, including music, clay art, traditional poetry, and cordel literature, 
particularly in the years of 1950, 1958, and 1970. This mixture of sources and narratives shows that World Cup football in the Northeast provided a space within which the terms of regional (and national) identity were contested and debated.

The examination of press coverage around the 1950 World Cup match in Recife focuses not only on the intended message, but also on the "noise" of communication, that is, according to Michel Sèrres (1982: 66), the obstacles, discontinuities, ambiguities, and contradictions found in discourse. Many writers in Pernambuco expressed the importance of the campaign to bring a match to Recife in regional and unifying terms, but within the noise of their communication, they indicate disagreement and anxiety within the project. Newspaper analysis shows the growing power of regional discourse to motivate northeasterners - in this case pernambucanos (people from the state of Pernambuco) - to mobilize around a campaign to bring international attention to the region, while also highlighting the fears that this international attention inspired. Due to the successful campaign to bring a World Cup match to the Northeast in 1950, northeasterners engaged directly with international football and expressed concerns about how the region would be perceived by a global audience.

Music, visual art, literature, and ceramic sculptures (cerâmica), on the other hand, suggested equal, democratic participation through regional media. These artistic creations do not explicitly do "region work", according to Anssi Paasi's (2010: 2300) definition — that is, they do not define the region, create regional institutions, or organize systematic activism; their work is more subtle. The origin of their product is apparent and, yet, does not conflict with a sense of national belonging. Instead, northeastern art focuses on harmony with the nation. Regional concerns are smoothed over in regional art and, while other anxieties (like racial inclusion) are given room, the focus is on celebration, unity, and the art of living within the football match.

\section{THE FORMATION OF THE BRAZILIAN NORTHEAST}

efore the $20^{\text {th }}$ century, there was no Northeast. The horrific drought of $1877-79$ led to
the creation of national institutions dedicated to lessening the effects of future droughts. By the 1920s, these institutions referred to the drought zone as the Northeast (Albuquerque Júnior, 2009: 81; Buckley, 2010). In contrast to São Paulo's regional identity based on notions of European ethnic origin, affluence, and cultural superiority, the Northeast became associated with a mixed race population, drought, migration, poverty, and inferiority (Albuquerque Júnior, 1987; Campbell, 2014; Weinstein, 2015). In response, intellectuals in the Northeast formed the first influential regionalist movement, aimed at emphasizing that the region had a positive 
cultural character. This movement was developed by the Regionalist Center of the Northeast in 1924 and represented at the Regionalist Conference in Recife in 1926 by Gilberto Freyre and other intellectuals (Campbell, 2014: Chapter 1).

In 1950, Recife would become the only northeastern city to host a World Cup match. At that time, Recife had over half a million inhabitants and the largest foreign population in the Northeast (Instituto Brasileiro de Geografia e Estatística, 1951: 27, 33, 61). In addition to passenger trains and buses, the state of Pernambuco had nearly 13,000 vehicles on its roads, about half of which were common passenger vehicles - more than any other state in the Northeast, including Bahia (Instituto Brasileiro de Geografia e Estatística, 1950: 174). Recife demonstrated the highest mortality rates and had the second highest cost of living in the country, while employing only $6.1 \%$ of the country's industrial laborers (Instituto Brasileiro de Geografia e Estatística, 1951: 63, 337, and 116). The campaign to bring a World Cup match to Recife often referred to an opportunity to improve the city and the region's reputation both nationally and internationally.

\section{THE WORLD CUP MATCH IN RECIFE}

T he campaign to bring a World Cup match to Recife got off to a slow start. In 1949, the directors of the Sport Club do Recife began a project to expand and modernize the llha do Retiro stadium, starting with the construction of the stadium seating. In February 1950, the Diário de Pernambuco published calls for donations of "cement, tiles, or money." Ary Dornelas (1950), who wrote these initial articles, reminded readers that this was not the first of Sport's "popular" campaigns - the land upon which the stadium was built had been purchased through a similar collection effort. These articles are the first to mention that the construction of the seating could lead to a World Cup match in Recife.

In April 1950, Laudenor Pereira, who wrote a regular column on the World Cup for the Diário de Pernambuco, heard of the possibility of Recife hosting a match in an interview with Rivadavia Correia, the President of the Brazilian Sports Commission (CBD), given to the Radio Tamoyo and retransmitted by the Ceará Rádio Clube. According to Correia, both Recife and Salvador (which would not host a match) were under consideration for World Cup matches. Pereira (1950a, 1950b) wrote that recifenses should prepare early and put effort into the construction of the seating at Ilha do Retiro. According to him, the World Cup matches in Recife would bring money to the city and would turn it into a center of international tourism. 
In May, the superintendent of the CBD, Irineu Chaves, visited Recife (Jornal Pequeno, May 13, 1950). After his visit, Chaves announced that two or three matches would take place in Recife upon completion of "a few minor improvements" to the llha do Retiro Stadium (Folha da Manhã, May 14, 1950; Diário da Manhã, May 14, 1950; Folha do Povo, May 12, 1950; Jornal Pequeno, May 15, 1950; Diário de Pernambuco, May 16, 1950 and May 17, 1950). The minor improvements included: increasing capacity by closing the ring of seating around the field, building fences to separate the players from the public, constructing locker rooms and tunnels, and improving the pitch (Santos, 1985: 1:201). Chaves expected earnings of $\mathrm{Cr} \$ 700,000.00$ per match. Hinting at the region's poverty, reputation of poor housing standards, and desire to direct the foreign gaze toward its positive attributes, he urged recifenses to "provide dignified lodging, because these are fine people who are accustomed to good treatment and, regardless of that, we must show our nobility ..." (Diário de Pernambuco, May 16, 1950).

Major donations for the construction of the Ilha do Retiro stadium in Recife came from both private and public donations (Diário da Manhã, May 28, 1950, Jun 7, 1950, and Jun 24, 1950). Senator Luiz Magalhães Melo presented a law to the Legislative Assembly proposing the donation of Cr\$200,000 to the CBD to support the match in Recife (Diário da Manhã, May 28, 1950, Jun 7, 1950; Diário de Pernambuco, Jun 6, 1950, Jun 8, 1950). On June 17, 1950, a modified version of the law was approved and $\operatorname{Cr} \$ 100,000$ were designated for both Náutico and Sport, with the remaining $\mathrm{Cr} \$ 100,000$ going to the Pernambucan Federation of Sports (Diário de Pernambuco, June 6, 1950; Diário de Pernambuco, June 18, 1950). In addition, a man named Adelmar Costa Carvalho donated an unspecified amount of money to Sport to cover the building of the locker rooms "in exchange for certain advertising privileges" (Diário da Manhã, June 24, 1950).

Small donations of supplies and labor were also visible and important, lending a democratic feel to the newspaper story of the 1950 World Cup in Recife. On December 17, 1949, the Diário de Pernambuco announced bingo fundraisers to help cover the costs of the seating. Nonetheless, on June 1st 1950 , Joca de Lira Ferreira of Sport appealed to Sport fans, explaining that he worried that "the CBD is repentant of having conceded with such ease this benefit to our Northern club" and might cut off promised funding and support. In his plea, he reminded recifenses of previous successful campaigns, and requested that each "little lion" donate newspapers or bottles, and even offered to pick up materials from homes. His request also included construction materials like "tiles, cement, sand, lime, iron, scrap metal, shovels, hoes, anything you might be able to contribute, even through sacrifice, ...". These donations would allow for the realization of "the golden dream not only of rubros negros, but of all 
Pernambuco's sincere sports fans" (J. de L. Ferreira, 1950). Artur Maciel pointed out that the "gigantic work in progress" was possible due to the "abnegados" - the "selfless" volunteers, fans, laborers, and donators of meals and materials repeatedly referenced in newspapers (Maciel, 1950).

This call for abnegation and self-sacrifice recalls explanations of nation and nationality. Ernest Renan saw the nation as a moral unit that requires sacrifice and self-denial (Renan, 1882: 26, 26-27, 27, and 29, respectively). Benedict Anderson added that the nation, like the family, is considered "interestless" and because of this, "can ask for sacrifices" (Anderson, 2006: 144). Sport, then, directed similar pleas to its fans as that of a nation and many Sport fans responded (see Figures 2-4). According to the book Memória Rubra Negro, at any given time there were dozens, even hundreds of volunteers working "as if laborers" (Santos, 1985, 1:201). Fernando Bivar, of Sport, described the stadium as "a true effort" that included "the right to breaks and lunch — sarapatel and feijoada ..." (Bivar, 2008, 53). Even regionalist writer José Lins do Rêgo offered his opinion: "The World Cup is carrying away all of the northeasterners ... I went to the Sport Club and I was delighted by the effort... shift after shift of laborers, night and day, in intense labor. I believe if everyone did as Sport of Recife, we would have throughout Brazil a World Cup capable of meeting all expectations" (Rêgo, 1950).

While Recife's newspapers attempted to create a narrative of cooperation and sacrifice, they left enough noise in the margins to indicate that not everyone was self-sacrificing, involved, or supportive of the international football match. The initial calls for donations drew immediate criticism from one of the Diário de Pernambuco's sports writers, Viriato Rodrigues. Rodrigues' article criticized the campaign, but also praised the directors of the club for their ability to get things done. Rodrigues says, for example, that Sport's members are supposed to "spontaneously bring tiles, a bag of cement, [that is, in the case of] the richest [fans]. Those who don't have any of this, can [just] bring money." And in this way, "the stadium seating will be finished. It will be mine, it will be yours, it will be everyone's, it will belong to Pernambuco. And when it is ready, no one will be able to jump the wall anymore and those who don't pay will have to pace in the entrance way. No one will get through" (Rodrigues, 1950a).

Rodrigues left the suggestion for the reader to complete: fans donated supplies or even money, but they would not even be able to enter the stadium. If they could afford to pay, they would enjoy matches free of riff-raff. But if they were the riff-raff, regardless of their sacrifice, there would be no display of horizontal, classless camaraderie: they would be left alone, standing at the gates. Rodrigues implied that while the stadium would figuratively belong to Pernambuco, it would only belong to the Pernambucans who could afford tickets (Rodrigues, 
April 4, 1950). On the other hand, in May 1950, Severino Almeida complained in the Jornal Pequeno that Sport had had no other choice but to ask the civilian patrol police to "prevent that people enter without paying." He quickly corrected himself: "The people, no. It's soldiers and all kinds of police officers who want to enter without paying." According to this article, the police and military officers expected to enter the stadium for free, creating "a great shame ... on our football pitches." Not everyone was willing to give quietly and to sacrifice for the stadium without receiving anything in return (Jornal Pequeno, May 3, 1950).

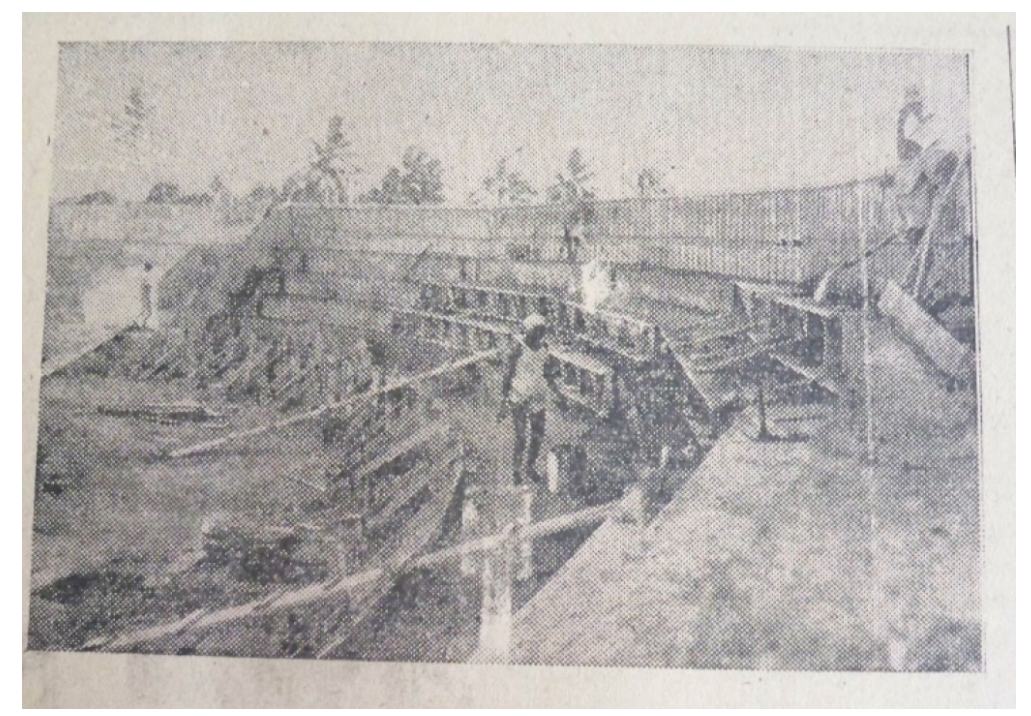

Figure 2: Construction work at the Illha do Retiro Stadium 1

Grievances over the construction of the stadium, the expenditure of funds, and the presence of foreign delegations did not come primarily from socialist newspapers. The Folha do Povo, for example, in its reporting of the construction of the llha do Retiro Stadium, of Irineu Chaves' visit to inspect the stadium, and of the match held in Recife, offered straightforward narrative, devoid of overt political insinuation (Folha do Povo, May 12, 1950, Jun 21, 1950, Jun 29, 1950, Jul 2, 1950). The effort and attention that the preparations for the match attracted instead upset some elite recifenses. One editorial, written under the pen name "Argus" insisted that so much attention given to sports was "excessive and harmful" as it detracted from "intellectual culture." Further, the language employed was "semi-barbaric" as fans wrote ofisaide and futebol "without remembering that these are English terms." Argus expressed disdain at seeing "illustrious" political representatives talking about sports at the Federal and Municipal Chambers (Argus, 1950). 
To this writer, sports were for physical fitness and had no place in local politics. At least one politician agreed with Argus. When addressing the state Legislative Asssembly to urge state and city administrators to support the matches in the Ilha do Retiro stadium, Representative Júlio de Melo Filho first asked his colleague Mário Melo for permission, describing him as "considered by many as the number-one enemy of football" (Jornal Pequeno, May 9, 1950).

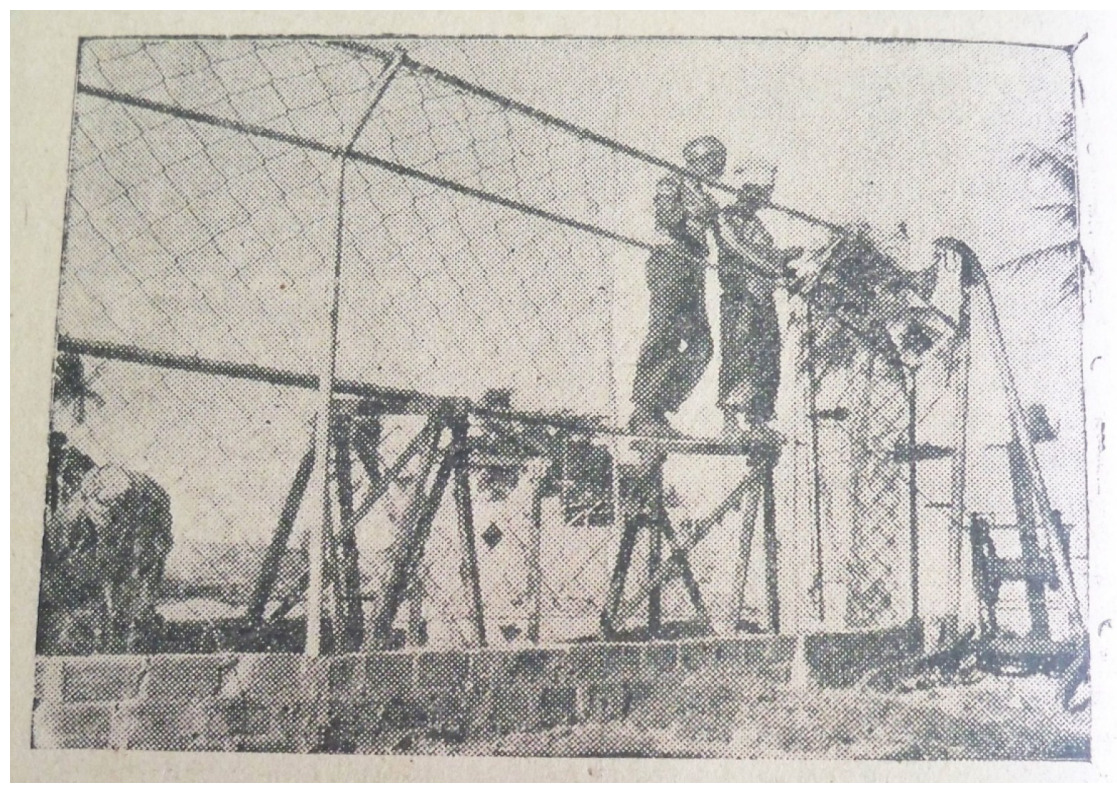

Figure 3: Construction work at the Illha do Retiro Stadium.

Other recifenses were concerned with the negative impression that travelers might take away from their visit to the city. Worries that tourists might speak poorly of Recife based on the unattractiveness of the areas surrounding the Náutico stadium (which had recently suffered a fire) and the llha do Retiro stadium (often surrounded by standing water) inspired petitions for the municipal government to create new parks and plazas near the stadiums (Diário da Manhã, Mar 29, 1950). Another concern expressed in the Diário da Manhã was over the quality of materials purchased with the donated money. The "magnificent locker rooms" were well-constructed, but the toilets, sinks, and faucets were of "proletarian" quality. "After all," an anonymous writer pondered, "money was offered for the construction of two model pavilions ... Why, then, was ordinary material used ...?" (Diário da Manhã, Jun 24, 1950). The writer worried the foreign delegations would see the poor quality and judge the entire effort and region accordingly. 


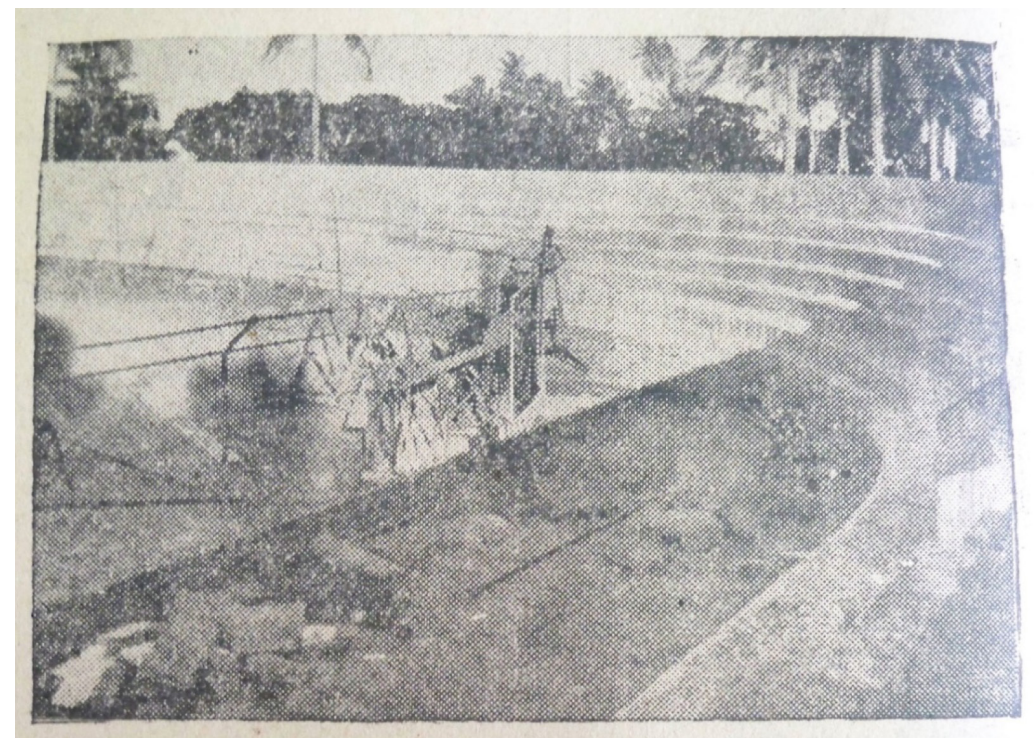

Figure 4: Construction work at the llha do Retiro Stadium.

Despite the proletarian faucets and unfortunate rain, the World Cup match took place in Recife on July $2^{\text {nd }}, 1950$. The América Futebol Clube from Recife and the América Futebol Clube of Fortaleza played an opening match, which the latter team won $2 \times 0$. Against projections, the USA team lost to Chile, with the final score: Chile 5, USA 2. The match had sold out and brought in a little more than Cr\$290,000. While this was far less than original expectations, newspapers mentioned only complete satisfaction with the event (Diário da Manhã, Jul 2, 1950; Pinho, 1950). Among the successes was the presence of illustrious guests in the audience, including the state Governor Barbosa Lima, the Mayor Morais Rêgo, military commanders, Chilean and US diplomats, representatives of the CBD, the president of the Federação Cearense de Futebol, members of the foreign press, and Jules Rimet, who praised the construction of the stadium (Diário da Noite, Jul 3, 1950; Diário de Pernambuco, Jul 4, 1950, Jul 8, 1950). 


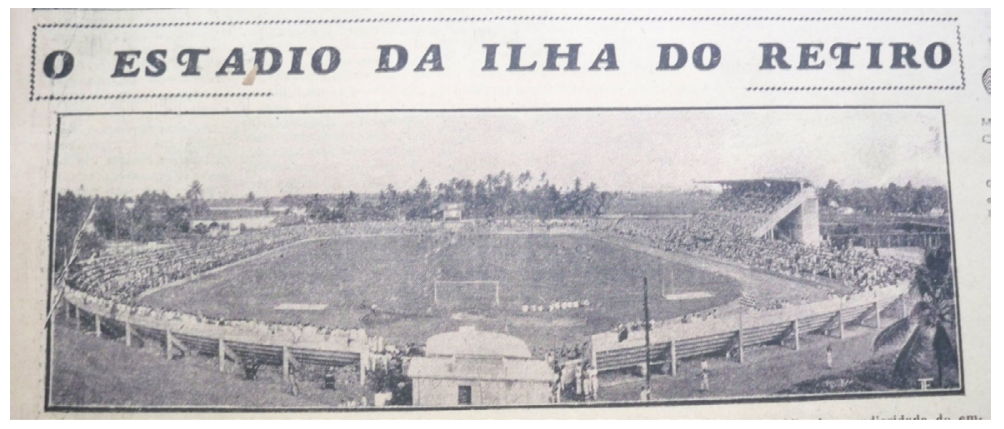

Figure 5: Ilha do Retiro Stadium (Diário da Manhã, Jul 4, 1950).

In the end, the greatest star on July $2^{\text {nd }}, 1950$ was the Ilha do Retiro stadium (Figure 5). In its first edition post-match, a large photograph of the stadium appeared on the first page of the second section of the Diário da Manhã (four pages before the write up) (Diário da Manhã, Jul 4, 1950). The Diário da Noite claimed the llha do Retiro Stadium as a source of pride "for the entire Brazilian Northeast" (Diário da Noite, Jul 3, 1950). Journalists from Recife were not alone in noting the quality of the stadium. The sports writer from the St. Louis Post-Dispatch, Dent McSkimming, when interviewed by the Diário da Noite stated that he and "the other members of the press corps from the United States are pleasantly surprised by the wonderful condition of the pitch here." According to McSkimming, the stadium was comparable to that of Belo Horizonte, a notable compliment whose regional implications were likely unknown to the North American journalist, but would inspire great pride to the northeastern newspaper (Diário da Noite, Jul 3, 1950). Nonetheless, while a Folha da Manhã article claimed that "the attentions of the whole world" would be on the llha do Retiro stadium, in the St. Louis PostDispatch article published on July $3^{\text {rd }}$, 1950, there is no mention of Recife or its new stadium (Folha da Manhã, Jul 2, 1950; St. Louis Post-Dispatch, Jul 3, 1950).

As the first television towers had just arrived in Rio de Janeiro in November 1949 and the World Cup would not be broadcast nationally in Brazil until 1970, radio transmissions were fundamental in the 1950 World Cup (Diário de Pernambuco, Oct 22, 1949, Nov 3, 1949). The Jornal do Commércio transmitted the World Cup matches and released to all broadcasters foreign and domestic — permission to re-broadcast their transmissions. This allowed the Diário de Pernambuco to re-transmit the World Cup matches through loudspeakers placed by the Radio Club of Pernambuco (Radio Clube de Pernambuco) on the outside of the Diário building, facing the Praça do Diário in downtown Recife (Diário de Pernambuco, Jul 1, 1950). These re-transmissions drew a crowd of recifenses who did not have a radio at home or who simply preferred to listen to the broadcasts in a group setting (see Figure 6) (Jornal Pequeno, Jul 17, 1950). 
For the USA-Chile match, journalists from Brazil, Chile, and the US were present, prepared to broadcast. At the beginning of the match, however, electrical power went out at the stadium, making it impossible for foreign and local media to transmit the match (Folha da Manhã, Jul 4 , 1950). Once Tramways (which was in charge of providing energy) had restored electricity to the stadium, the power fell again, this time, reportedly due to cut cables. According to one article, "The loose-lipped say it was sabotage..." - hardly the language of trust, unity, and horizontal camaraderie (Diário da Noite, Jul 3, 1950).

The campaign to bring a World Cup event to Recife created a centerpiece for a discussion of regional inequalities, representation, shame, and pride. The construction of the Ilha do Retiro stadium and the realization of the first World Cup match played in the North or Northeast also testifies to the plurality of the process of regional identity formation. While some recifenses saw football as a way to demonstrate regional progress, others saw it as a waste of time. While Recife newspapers insisted on harmony with Bahia to promote northeastern unity, the Bahian newspaper A Tarde ignored this aspect. Even supporters hinted at misgivings over the possibility that foreigners noticed the poor quality constructions or the lack of parks. In this way, the event opened a space within which the media could discuss the place of the Northeast in the nation and the world.

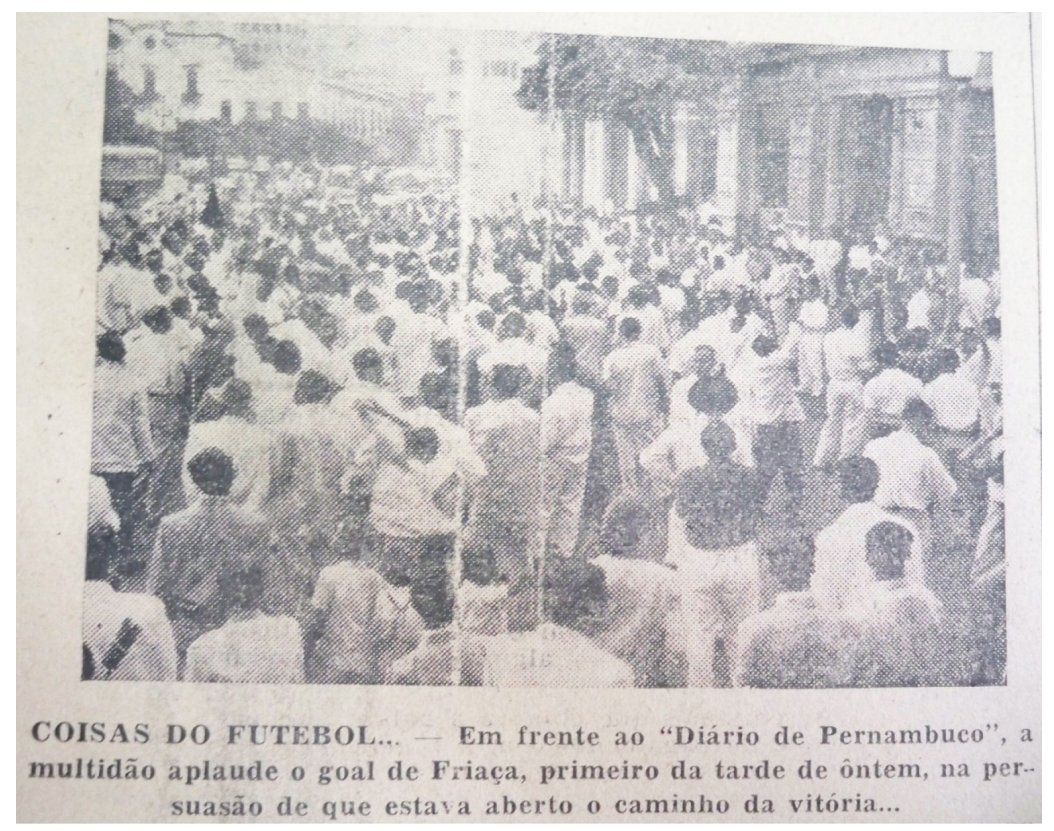

Figure 6: Crowd listening to the final World Cup match outside the Diário de Pernambuco building (Jornal Pequeno, Jul 17, 1950). 


\section{THE WORLD CUP IN REGIONAL ART AND ESSAYS}

ootball also found a place within northeastern literature and art. The northeastern poet
João Cabral de Melo Neto, for example, dedicated several poems to northeastern football and one specifically to Ademir Marques de Menezes, entitled "A Ademir Meneses." By the end of the 1950 World Cup, Menezes held the record as highest scoring football player, with nine goals over the course of the tournament (Jornal Pequeno, Jul 19, 1950). One Jornal Pequeno article exalted him as "the greatest player in Brazil" reminding the reader that he "learned to play in the [Sport] Club of the Ilha [do Retiro]." The writer referred to Ademir as "one of the glories of the rubro-negro family" and "a home raised player that has shined in an international setting" (Jornal Pequeno, May 13, 1950). Melo Neto's poem connected Menezes to the player's pernambucanidade (inherent qualities of being from Pernambuco), focusing on the influence of environment and climate on his football style. Neto pointed out that Ademir, "like other recifenses" was born among "mangroves and frevo" and was "divided / between two different climates / ambidextrous in drought and humidity / as in general are recifenses" (Neto, 1988). Like Gilberto Freyre in Nordeste, Melo Neto united the "two Northeasts", that is, he drew the sertanejo (of Freyre's "other Northeast") and the coastal dweller (of Freyre's "Northeast of sugarcane") together (Freyre, 1961, XI). In Melo Neto's poem, Menezes was not only a high scoring player, but the embodiment of a unified northeastern football. To the poet, Ademir's craft and origin could not be separated.

Melo Neto's joining of region and football capability was part of a trend to describe Brazilian football talent as determined by race, nation, or region of origin. In 1938, Freyre's article, "Foot-ball mulato," was published in Diários Associados' newspapers, including the Diário de Pernambuco. In it, Freyre praised Brazil for sending a team that was mainly AfroBrazilian to the World Cup in France (see also: Maranhão, 2019). To Freyre, what made Brazil's football stand out was what he considered its psychologically mulatto style — that is, a style that was not racially determined, but that was created by a mulatto culture. The qualities of this style included "surprise, dexterity, guile, and lightness and, at the same time, individual spontaneity." Freyre compared the Brazilian/mulatto way of playing football to dance and capoeira, claiming that Brazilian players "round out and sweeten the game invented by the English" which the Europeans play "so angularly." Freyre stated that "to be Brazilian is to be mulatto" - a way of being that values spontaneity, improvisation, and freedom to show off personal talent (Freyre, 1938). Like Freyre, Melo Neto joined craft and origin in his poem.

Unlike Melo Neto's poem, most regionalist art did not focus on northeastern players or the only match to be played in Recife. Instead, it presented international sporting events and 
national heroes in regional form. The Pernambucan writer Ascenso Ferreira, for example, also wrote poetry about the World Cup, connecting football to humor and sexuality. In "A Copa do Mundo," Ferreira narrated a reunion of two lovers - Maria and Chico Tenório — who had long been meeting "off-side." Maria took advantage of the confusion caused by one of Brazil's World Cup victories to invite Chiquinho to "make our own goal" (Ferreira, 2016, s.p.). In this and similar tales of victory, there is no overt message of northeastern regional identity or unity. Instead, the quotidian unfolds in a context of national celebration in northeastern cities.

Football also pervades visual arts associated with the Brazilian Northeast. The cearense painter Aldemir Martins, internationally acclaimed, yet known for regional themes in his paintings, created expressive works on football. While Martins is known for his representations of elements considered typical from the state of Ceará (bandits, lace makers, fruits, animals, and sertanejos), his best known football painting is of Pelé (who was born in Minas Gerais, not in the Northeast). In these paintings, Martins used his well-known regional style to portray a national football hero. For example, in Martins' painting Pelé (see Figure 7), Pelé comes through in thick solid borders over sparse color, giving a rustic impression to the subject matter. Pelé reaches forward with both arms, one leg bent back to kick the ball in front of him. Pelé is faceless and our only indication to his identity (besides the title) is the number 10 from the back of his jersey, which the privileged reader is able to see from the side, in cubist fashion. Similarly, the Museu do Homem do Nordeste houses cerâmicas — another visual art form considered typical of the Northeast - by Mestre Vitalino and Rosa of Caruarú. Rosa's football player wears the national jersey (see Figure 8). In these cases, artists whose careers were built on the northeasterness of their work, used their regional art to present a national, rather than regional, symbol.

These works address national symbols and themes (the World Cup, Pelé, Brazilian soccer players) within northeastern art forms. In this way, they place themselves in conversation with both regional and national topics and debates. A prime example of this is Jackson do Pandeiro's song Um a um (1x1). The chorus of the song repeats that the singer's team is "red, white, and black, it's red and black / it's red, black, and white, it's red and white" (UM, 1954). The song, according to Pandeiro, was originally written for Pernambuco as a "catch all" song - red, white, and black are the colors of Santa Cruz, red and black of Sport, and red and white of Náutico. Pandeiro added: "Everywhere in Brazil there are these colors, in Rio, in São Paulo, in Bahia, this music was just for Pernambuco. But ... we set it up to catch all of Brazil" (Souza, 2000: 119-20). 
The most pervasive example of national football presented in regional form are the hundreds of cordel pamphlets on the theme of football, ranging from the 1940s to the present, housed in archives throughout the Northeast and in Rio de Janeiro. Cordel literature is one of the most recognizable popular northeastern cultural products. It likely derives from the European pamphleting tradition, which arrived with the Portuguese in the sixteenth and seventeenth centuries. Yet, by the nineteenth century, it had nearly taken on its current form (Curran, 1991: 9). At its most basic, a cordel pamphlet is simply a piece of paper folded twice (once horizontally, once vertically) and cut at the seams to create a booklet of eight pages, but sometimes much longer, with a cover that is often of a pastel color and whose illustration, depending on the year of production, could range from a simple title to a wood cut print.

The extended poem within the pamphlet is usually composed of verses of six or seven lines of eight syllables with either an $A B C B D B$ or $A B A B C C B$ rhyme scheme (10). Most cordel are divided between what Veríssimo de Melo referred to as "records of memorable facts, in pamphlet form" or fictional "narrative in verse" (Melo, 1976: 51). As Melo pointed out, modernization did not force cordel pamphlets into the background. Instead, cordel coexists alongside radio and television (and now, the internet), communicating information to a large audience in an engaging form (52).

In the $20^{\text {th }}$ century, writing cordel was a hobby for some, but for others, it was a profession. Cordel poetry was not intended solely for personal, private reading. It was also a form of performance. Cordelistas would read (or sing out) their work in markets and squares throughout the Northeast with great exuberance and animated gestures to advertise their goods, and those who purchased the literature might read aloud and share with others who did not know how to read (Curran, 1991: 19). According to Candace Slater, members of the land-owning classes also often read the literature aloud to their illiterate workers, and, in this way, participated in its selection and distribution (Slater 1982, 1-2). Further, migration from the Northeast to the Amazon, the South, and Southeast spread cordel literature throughout the country.

Most football-themed cordel literature narrates a victorious World Cup tournament or its final match. O Brasil na Copa do Mundo and A vitória do Brasil na VI Copa do Mundo, for example, relate each match, praise the players and the coach, and claim that Brazil's 1958 World Cup win was one of Brazil's greatest glories (Gomes, 1958; D'Almeida Filho, 1958). The rare mention of regions evokes a sense of national unity instead of divide. $O$ Brasil, campeão do mundo, for example, summarizes the World Cup match of 1958. Its author, Francisco Firmino de Paula, states: "In Brazil from north to south / or better said, in each state / whoever 
has a radio had / it turned on and ready / whoever didn't have one / went to a friend's house I to hear the result." According to this poem, the World Cup event, through radio, united the nation in the act of listening across state and regional borders (1958: 3).

Further, Paula highlights that the whole country participated in one great party, "For example in Recife / the joy was so great / that the people brought back Carnival ...". What makes these mentions of horizontal camaraderie across states and regions so striking is that 1958 was a drought year in the Northeast. Paula states that through the victory and resulting party, the people forgot "the dearth / people who haven't eaten in a month / on Sunday forgot their hunger / [and] joined the party" (1958: 8). World Cup victory in these pamphlets provided a way to celebrate national belonging, regardless of regional inequalities.

In 1962 and 1970, both years in which Brazil won the World Cup tournament, this form of cordel reappears, but other characteristics of Brazilian nationality began to surface. W. Pinheiro, in a cordel that details each match of the 1970 World Cup, explains that Brazil should serve as an example for the rest of the world. According to Pinheiro, instead of dedicating itself to war, Brazil focuses on football, played with equality and allowing everyone to live freely and in peace (1970: 16). Another cordel from 1970 exclaims: "Long live the hero players / that give to Brazil a celebration / the cup came to us / and our pleasure remains / we all tremble with joy / both in city and in forest" (Borges, 1970: 3). Rural or urban, North and South, in cordel literature on the World Cup, regions are invoked to emphasize unity.

In addition to these nonfictional narratives, there are more fantastical football stories in cordel form. Similar to Futebol no inferno, the undated cordel pamphlet Um futibol na cidade dos pássaros provides a detailed description of a football match between fictional characters. These pamphlets mimic the play-by-play form, providing a detailed narrative of a fictional match or tournament. This cordel pamphlet narrates the match between Esporte Clube Sulista (Southern Sport Club) and Esporte Clube Sertão (Backlands Sport Club). The geographic designations of "southern" and "backlands" hint at the social significance of such a rivalry, but in their ambiguity, draw the reader into a scene that could just as easily unfold in Arapongas, in Bahia, in the interior of São Paulo, or in the Amazon.

In Um futibol na cidade dos pássaros, each player is a different bird that the author, Minelvino Francisco Silva (from the state of Bahia), carefully describes before narrating the match. He also mentions females — a rare occurrence in football literature — devoting an entire page to descriptions of which birds were kissing in the bleachers. Um futibol na cidade dos pássaros is also unique in mentioning racial exclusion from sports. When a vulture arrives and asks if it can join a team, he is not only rejected, but told that "blacks are left out." Silva 
makes sure that the reader understands his suggestion, stating "the truth is that from sports the vulture was always excluded", surely making reference to the restrictions on Afro-Brazilian players in soccer clubs in Brazil throughout the first half of the $20^{\text {th }}$ century (Silva, n.d.: 2). ${ }^{2}$

In Silva's poem, the team from the backlands (presumably the northeastern team) defeats the southern team 2-0, but Silva is cautious and does not write fanfare into this victory, referring to it as "lero-lero", that is, as lacking importance (Silva, n.d.: 8). In the end, the emphasis in fictional cordel poetry like Um futibol na cidade dos pássaros and 0 futebol no inferno is on how the match is played, what happens in the bleachers, and who is and is not included. It is how football is lived, not won, that matters.

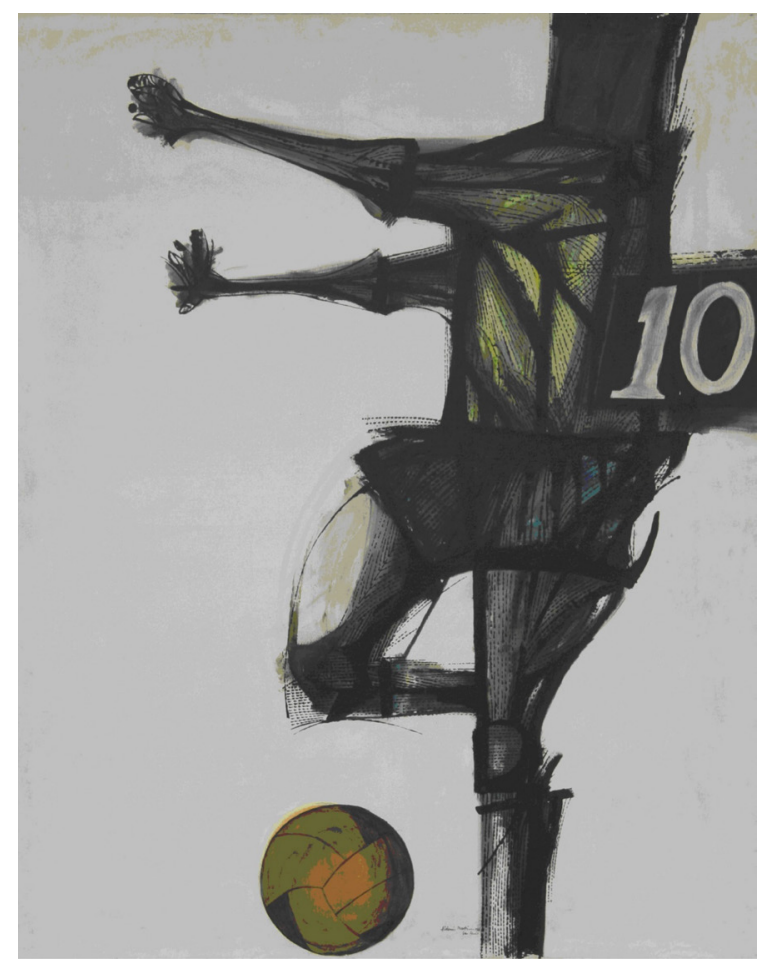

Figure 7: Pelé, by Aldemir Martins (1966). 


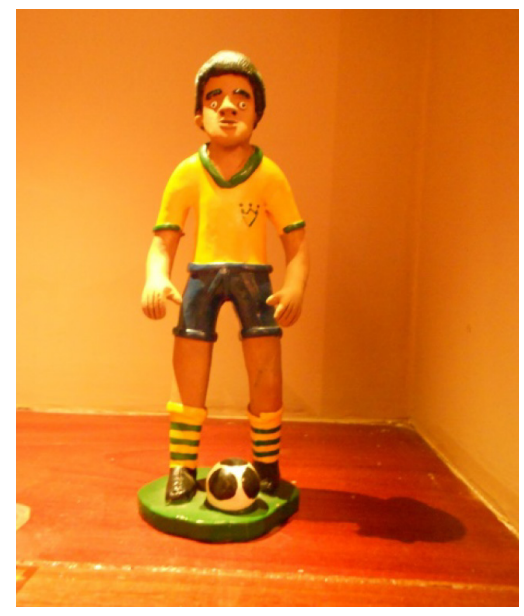

Figure 8: Jogador de futebol, by Rosa (n.d.).

\section{CONCLUSION}

I n 1950, Recife newspapers pushed a regional agenda to bring a World Cup match to the city. It was this regional agenda that motivated people to donate their own labor, whether through meal preparation for workers or construction work at the stadium. Connecting pride and hard work to a sense of northeasterness, showing what the Northeast was capable of, and sacrificing for the region (while fearing exposing the region's shortcomings or inferiority) these motivations were strong enough to fuel a campaign that brought Jules Rimet himself to Recife for the World Cup event. Much like nationalism, this regionalist sentiment was strong enough to unite people, but what motivated them to act was the possibility of an international audience. Brazilians had already identified the region as a national problem or obstacle to be overcome; the international event provided a new audience to whom northeasterners could instead show the region's attributes with pride. The success of the event was measured through the presence and praise of its international visitors.

Newspapers pushed a northeastern agenda, vying for greater resources and participating in a campaign to bring the World Cup to Recife. Their discourse, as such, was political, contentious, and always indicated a third, unspoken element - that the possibility existed that the Northeast would not participate in the nation, that it fall behind the nation not only in terms of poverty, infant mortality, and literacy, but also in sports. The newspapers in this sense were intentionally proving the worthiness of the Northeast, but their discourse also hinted, implicitly, at fears of inferiority and alienation — elements of northeastern identity that proved so pervasive that they have become essential to understanding the Brazilian Northeast. 
Regional art, produced later and often focused on Brazilian World Cup victories, employed a different type of regional representation: it subtly showed that the Northeast, its culture, and its folkloric symbols are particular, yet also belong to a world beyond regional borders. Regional art rooted for the national selection, celebrated Brazilian victory, saw its players reflected in the nation, and reflected national players in its art. Cordel literature on football rarely mentions the Northeast. Instead, regional art provided a forum for stressing inclusion within the nation and or expressing other national anxieties. Regional art, for example, focused on athletes' and the fans' masculinity by mentioning women only as sexual partners and presented anxiety over racial exclusion in football.

The cordel pamphlet with which this chapter opened, O futebol no inferno, like other examples of cordel poetry, regional music, and art, is coded to show the reader that what he or she is reading (or witnessing) is northeastern. It is written in cordel form, which is strongly associated with the Northeast. Berimbau (the referee) is the name of the musical instrument used to maintain rhythm in capoeira, also strongly associated with the Northeast - particularly with the cities of Salvador and Recife. Leather hats are typical of cattle ranchers in the backlands of the Northeast and versions of these were worn by the infamous bandit Lampião and his followers, all of whom lived and died in the Northeast. Even Satan has his northeastern side, appearing frequently as a main character in cordel literature and film.

Yet, each of these elements cannot be restricted to the Northeast. Cordel is also found in the Amazon and in Rio de Janeiro, carried by northeastern migrants to these regions. Capoeira is found in Rio de Janeiro and bandits, while from and acting within the Northeast, were found in countries throughout the world. Cachaça is distilled in the Northeast, but also in Minas Gerais, and Satan is featured in folkloric literature and music throughout the continent. In this way, the cordel is coded for recognition as northeastern, but fits within national and even international symbolic systems and debates.

To understand how art on World Cup football harmonizes with the nation without eschewing its regional particularities, we need to let go of a regionally reifying singular narrative, or, as in the case of Um futebol no inferno, we have to let go of an outcome. After tying, Lampião finds every excuse to postpone the deciding match. Once it starts, the match goes on for three days, but Satan decides to postpone finishing the match until Judgement Day. Hell is relatively new and they still need to finish the floor. Selling a few more tickets might just make that happen. In Futebol no inferno, everyone procrastinates and nobody wins. They do not need to; it is how the game is played, lived, and talked about that matters. Similarly, the importance of football within regional identity formation is not about what is defined, 
narrated, argued, and concluded, but what debate, multivalence, and art it inspires. While northeastern identity is defined by intentional, intellectual definitions, its character comes to life in art, everyday discussions, and noisy debate.

\title{
NEWSPAPERS CONSULTED
}

\author{
A Tarde (Salvador) \\ Diário da Manhã (Recife) \\ Diário da Noite (Recife) \\ Diário de Pernambuco (Recife) \\ Folha da Manhã (Recife) \\ Folha do Povo (Recife) \\ Jornal Pequeno (Recife) \\ St. Louis Post-Dispatch (St. Louis)
}

\section{NOTES}

1 Figures 2-4 are from Jornal Pequeno, 15 June 1950, 4.

2 See Lopes, 1998, 2000; Bocketti, 2016; Filho, 2010 for more on the history of race and exclusion in Brazilian football..

\section{BIBLIOGRAPHY}

ALBUQUERQUE JÚNIOR, Durval Muniz de. Falas da astúcia e de angústia: a seca no imaginário nordestino, de problema á solução (1877-1922). 1987. Dissertation (M.A. in History) — Instituto de Filosofia e Ciências Humanas, Universidade Estadual de Campinas, Campinas, 1987.

. A invenção do nordeste e outras artes. 4 ed. São Paulo: Cortez, 2009.

ALBUQUERQUE JÚNIOR, Durval Muniz. The Invention of the Brazilian Northeast. Translation: Jerry Dennis Metz. Durham: Duke University Press, 2014. 296 p. Original title: A invenção do Nordeste e outras artes. ISBN13, 978-8524914850.

ANDERSON, Benedict. Imagined Communities. New York: Verso, 2006.

ARGUS. Tópico do dia. Diário da Manhã, Hemeroteca, Arquivo Público Estadual Jordão Emerenciano, Recife, Pernambuco, sec. 2, 2 jun. 1950. 
THE NORTHEAST PLAYS FOOTBALL, TOO: WORLD CUP SOCCER AND REGIONAL IDENTITY IN THE BRAZILIAN NORTHEAST

BARRETO, Túlio Velho. Dossiê 1958: Futebol e identidade nacional. Continente multicultural, Recife, Pernambuco, 15 jan. 2008, p. 20 - 23.

BIVAR, Fernando Caldas. Coração rubro-negro. Recife: FASA, 2008.

BLAKE, Stanley. The Vigorous Core of Our Nationality: Race and Regional Identity in Northeastern Brazil. Pittsburgh: University of Pittsburgh Press, 2011.

BOCKETTI, Gregg. Invention of the Beautiful Game: Football and the Making of Modern Brazil. Gainesville: University of Florida Press, 2016.

BORGES, José Francisco. Brasil $4 \times 1$ trí campeão. 1970. 8 f. Printed on paper.

BUCKLEY, Eve Elizabeth. Drought in the sertão as a natural or social phenomenon: establishing the Inspetoria Federal de Obras Contra as Secas, 1909-1923. Boletim Museu Paraense Emílio Goeldi Ciências Humanas, Belém, v. 5, n. 2,p. 379-398, 2010.

CAMPBELL, Courtney J. The Brazilian Northeast, Inside Out: Region, Nation, and Globalization (1926-1968). 2014. PhD Dissertation (PhD in History) - Graduate School of Vanderbilt University, Vanderbilt University, Nashville, 2014.

CURRAN, Mark J. La literatura de cordel brasileña: antología bilingûe. Madrid:Orígenes, 1991.

D’ALMEIDA FILHO, Manoel. A vitória do Brasil na VI Copa do Mundo. 1958. 12 f. Printed on paper.

DAMO, Arlei Sander. Ah! Eu Sou Gaúcho. Revista Estudos Históricos, v. 13, n. 23, p. 87-118, 1999.

DORNELAS, Ary. Auspiciosa campanha social no Esporte Clube do Recife. Diário de Pernambuco, Setor Microfilmagem. Fundação Joaquim Nabuco, Recife, Pernambuco. 28 fev. 1950.

FERREIRA, Ascenso. Como polpa de ingá maduro: poesia reunida de Ascenso Ferreira. Recife: Companhia Editora de Pernambuco, 2016.

FERREIRA, Joca de Lira. 1950. Apêlo aos rubro-negros. Diário da Manhã, Hemeroteca, Arquivo Público Estadual Jordão Emerenciano, Recife, Pernambuco, sec. 2, 1 jun. 1950.

FILHO, Mario. O Negro no Futebol Brasileiro. Rio de Janeiro: Mauad Editora Ltda, 2010.

FREYRE, Gilberto. Foot-ball mulato. Diário de Pernambuco, Setor Microfilmagem, Fundação Joaquim Nabuco, Recife, Pernambuco, 17 jun. 1938.

Prefácio à 1a edição. In: FREYRE, Gilberto (org.). Nordeste: aspectos da influência da cana sôbre a vida e a paisagem do Nordeste do Brasil. Rio de Janeiro: José Olympio, 1961. p. 24-26.

GOMES, José. O Brasil na Copa do Mundo. 1958. 12 f. Printed on paper.

HELAL, Ronaldo. A lei, a ordem e o espetáculo: reflexões sobre a organização do futebol brasileiro. Cultura vozes, v. 92, n. 2, p.88-103, 1998.

HOBSBAWM, Eric J. Nations and Nationalism since 1780: Programme, Myth, Reality. Cambridge: Cambridge University Press, 1990.

INSTITUTO BRASILEIRO DE GEOGRAFIA E ESTATÍSTICA. Anuário estatístico do Brasil, ANO XI - 1950. Rio de Janeiro: Instituto Brasileiro de Geografia e Estatística. Available at: http://biblioteca.ibge.gov.br/visualizacao/ periodicos/20/aeb_1950.pdf. Accessed on: 22 jan. 2014. 
Anuário estatístico do Brasil, Ano XI - 1951. Rio de Janeiro: Serviço Gráfico do Instituto de Geografia e Estatística.

. Estatísticas históricas do Brasil: séries econômicas, demográficas e sociais de 1550 a 1988. 2 ed. Rio de Janeiro: Instituto Brasileiro de Geografa e Estatística, 1990.

KLINTOWITZ, Jacob. 1968. Aldemir Martines: Natureza a Traços e Cores. [s.I.]: Valoart.

LOMNITZ-ADLER, Claudio. Nationalism as a Practical System: Benedict Anderson's Theory of Nationalism from the Vantage Point of Spanish America. In: CENTENO, Miguel Angel; LÓPEZ-ALVES, Fernando (orgs.). The Other Mirror: Grand Theory through the Lens of Latin America. Princeton: Princeton University Press, 2001. p. 329-260.

LOPES, José Sergio Leite. Fútbol y clases populares en Brasil. Color, clase e identidade através del deporte. Nueva Sociedad, n. 154, p. 124-46, 1998.

. Class, Ethnicity and Color in the Making of Brazilian Football. Daedalus, v. 129, n. 2, p. 239-70, 2000.

MACIEL, Artur. Tirando o chapéu. Diário da Manhã, Hemeroteca, Arquivo Público Estadual Jordão Emerenciano, Recife, Pernambuco, 26 mar. 1950.

MARANHÃO, Tiago J. 2019. "Let the Aryanists Know! Brazilian Race and Nation in the 1938 France World Cup." Soccer \& Society, 16 Oct. 2019. Available online at: https://doi.org/10.1080/14660970.20 19.1680492. Accessed on: 20 Oct. 2019.

MARTINS, Aldemir. Pelé. 1966. 1 quadro, óleo sobre tela, 130 x 165 cm. Coleção Pinacoteca do Estado de Ceará.

MEIHY, José Carlos Sebe Bom. Para que serve o futebol? In: MEIHY, José Carlos Sebe Bom; WITTER, José Sebastião (orgs.). Futebol e cultura: coletânea de estúdios. São Paulo: IMESP/DAESP, 1982. p. 11-19.

MELO, Veríssimo de. Origens da literatura de cordel. Tempo universitário, v. 1, n. 1, p. 41-47, 1976.

NETO, João Cabral do Melo. Museu de tudo e depois. Rio de Janeiro: Editora Nova Fronteira, 1988.

OLIVEN, Ruben George. 0 nacional e o regional na construção da identidade brasileira. Revista Brasileira de Ciências Sociais, v. 1, n. 2, p. 68-74, 1986.

. A parte e o todo: a diversidade cultural no Brasil-nação. Petrópolis: Vozes, 1992.

PAASI, Anssi. Regions Are Social Constructs, but Who or What 'Constructs' Them? Agency in Question. Environment and Planning $A$, v. 42, p. 2296-2301.

UM a um (1x1). Intérprete: Jackson do Pandeiro. Compositor: Jackson do Pandeiro. Rio de Janeiro: Copacabana, 1954. Acessado como Mp3. 5.234-a, Arquivo Nirez, Fortaleza, Ceará.

PAULA, Francisco Firmino de. O Brasil Campeão do mundo. 1958. 12 f. Printed on paper.

PEREIRA, Laudenor. Campeonato do mundo. Diário de Pernambuco, Setor Microfilmagem, Fundação Joaquim Nabuco, Recife, Pernambuco.27 abr. 1950a.

. Onde estão os deportistas. Diário de Pernambuco, Setor Microfilmagem, Fundação Joaquim Nabuco, Recife, Pernambuco, 28 abr. 1950b.

PINHEIRO, W. Brasil tri-campeão, toda história da taça que é nossa pra sempre. Natal: Clima, 1970. 
THE NORTHEAST PLAYS FOOTBALL, TOO: WORLD CUP SOCCER AND REGIONAL IDENTITY IN THE BRAZILIAN NORTHEAST

PINHO, Nilson Sabino. Brilhante exibição dos andinos. Diário da Manhã, Hemeroteca, Arquivo Público Estadual Jordão Emerenciano, Recife, Pernambuco, sec. 2, 4 jul. 1950.

RÊGO, José Lins do. 0 esfôrço do Sport Clube, de Pernambuco. Diário da Manhã, Hemeroteca, Arquivo Público Estadual Jordão Emerenciano, Recife, Pernambuco, sec. 2, 8 jun. 1950.

RENAN, Ernest. Qu'est-ce qu'une nation? 12a ed. Paris: Calmann Lévy, 1882.

RODRIGUES, Viriato. Uma campanha e tanto ... Diário de Pernambuco, Setor Microfilmagem, Fundação Joaquim Nabuco, Recife, Pernambuco, 2 mar. 1950a.

O Esporte Clube do Recife e as suas realizações em andamento. Diário de Pernambuco, Setor Microfilmagem, Fundação Joaquim Nabuco, Recife, Pernambuco, 4 abr. 1950 b.

ROSA. n.d. Jogador de futebol. 1 escultura, cerâmica. Coleção do Museu do Homem do Nordeste.

SANTOS, Manoel Heleno Rodrigues dos. Memória Rubra-Negro (1905-1955): Sport Club Recife "Cinquenta anos de glória." Vol. 1. Recife: M. Inojosa, 1985.

SERRES, Michel. Hermes: Literature, Science, Philosophy. Baltimore: John Hopkins University Press, 1982.

SILVA, Minelvino Francisco. Um futibol na cidade dos pássaros. s.d. 12 f. Printed on paper.

SLATER, Candace. Stories on a String: The Brazilian Literatura de Cordel. Berkeley: University of California Press, 1982.

SOARES, José. O futebol no inferno: a melhor de três. s.d. 12 f. Printed on paper.

SOUZA, Tarik de. Jackson do Pandeiro. In: SOUZA, Tarik (org.). A música brasileira deste século por seus autores e intérpretes, São Paulo: SESC, 2000. p. 117-133.

WEINSTEIN, Barbara. Brazilian Regionalism. Latin American Research Review, v. 17, n. 2, p. 262-276, 1982.

WEINSTEIN, Barbara. The Color of Modernity: São Paulo and the Making of Race and Nation in Brazil. Durham and London: Duke University Press, 2015. 